
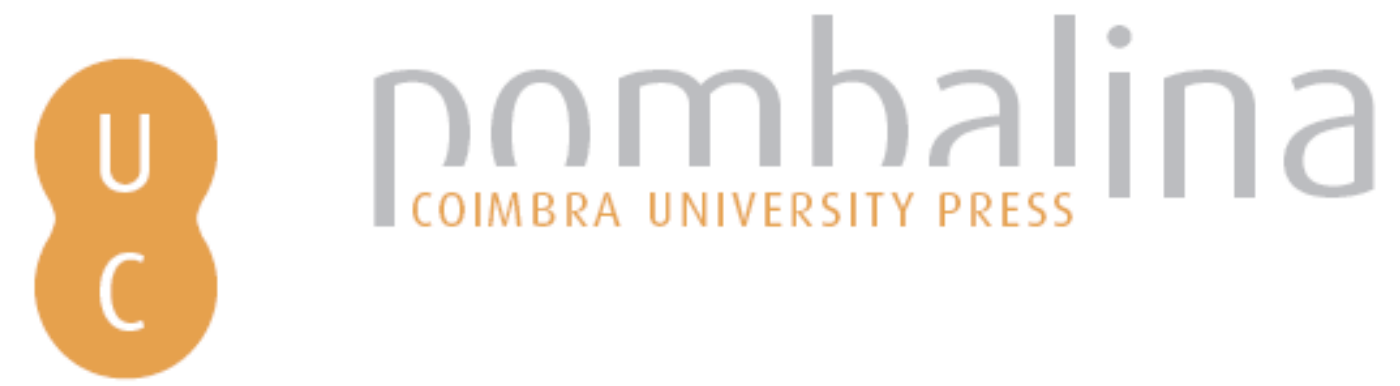

\title{
Educação e Brasil na Primeira República
}
Autor(es):
Bomeny, Helena

Publicado por: Imprensa da Universidade de Coimbra

URL

persistente:

URI:http://hdl.handle.net/10316.2/35880

DOI:

DOI:http://dx.doi.org/10.14195/978-989-26-0862-4

Accessed : $\quad$ 26-Apr-2023 03:38:35

A navegação consulta e descarregamento dos títulos inseridos nas Bibliotecas Digitais UC Digitalis, UC Pombalina e UC Impactum, pressupõem a aceitação plena e sem reservas dos Termos e Condições de Uso destas Bibliotecas Digitais, disponíveis em https://digitalis.uc.pt/pt-pt/termos.

Conforme exposto nos referidos Termos e Condições de Uso, o descarregamento de títulos de acesso restrito requer uma licença válida de autorização devendo o utilizador aceder ao(s) documento(s) a partir de um endereço de IP da instituição detentora da supramencionada licença.

Ao utilizador é apenas permitido o descarregamento para uso pessoal, pelo que o emprego do(s) título(s) descarregado(s) para outro fim, designadamente comercial, carece de autorização do respetivo autor ou editor da obra.

Na medida em que todas as obras da UC Digitalis se encontram protegidas pelo Código do Direito de Autor e Direitos Conexos e demais legislação aplicável, toda a cópia, parcial ou total, deste documento, nos casos em que é legalmente admitida, deverá conter ou fazer-se acompanhar por este aviso.

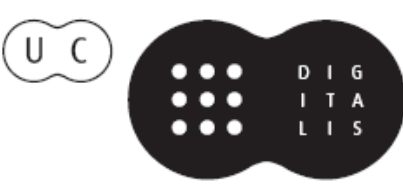




\title{
A EXPERIÊNCIA DA PRIMEIRA REPÚBLICA NO BRASIL E EM PORTUGAL
}

\author{
ALDA MOURÃO \\ ANGELA DE CASTRO GOMES
}

COORDENAÇÃO 


\section{Educação e Brasil na Primeira República}

Helena Bomeny

ATRAVEZ DO BRAZIL, TAL COMO FOI GRAFADO NO ORIGINAL, É O TÍTULO DE UM livro escrito por Olavo Bilac e Manoel Bomfim, em 1910, que chegou, em 1930, à vigésima edição revista pela Livraria Francisco Alves. O livro tem como subtítulo "Livro de leitura para o curso médio das Escolas Primárias". Na seção intitulada "advertência" encontramos a fala dos autores: "a fim de ser ele o único livro destinado às classes desse curso; tal é, de fato, a indicação pedagógica aconselhada hoje: às primeiras classes do ensino primário não deve ser dado outro livro além do livro de leitura". O livro é tocante desde as primeiras linhas. "Uma simples narrativa", como anunciam os autores, a obra foi completamente bem-sucedida no propósito de capturar o interesse do leitor já na primeira página. Os autores Olavo Bilac (18651918) e Manoel Bomfim (1868-1932) fazem parte do conjunto de seletos escritores de livros didáticos da Primeira República, além de serem duas referências obrigatórias quando o que se pretenda seja a recuperação dos debates sobre educação no Brasil.

O enredo é envolvente: a saga de dois irmãos, Carlos e Alfredo, de 15 e 10 anos, respectivamente, órfãos de mãe, que fogem do colégio em Recife à procura do pai, engenheiro, que foi obrigado a deixá-los no internato para trabalhar na construçáo de uma estrada de ferro no interior do estado. Era a primeira vez que se separava dos filhos desde a morte da mulher. Pai amoroso e meigo, tornou-se ainda mais amoroso depois da perda da mulher como que a compensar ou aliviar a dor dos menores da falta dos cuidados maternos. "Não castigava nunca os filhos: era para eles um amigo, um camarada, um companheiro." 
O tom da relação entre os irmãos está impresso na recomendação feita pelo pai no momento da separação involuntária: "Vocês devem ser sempre muito amigos, muito unidos, tendo um só coração e uma só vontade. Não temos parentes por aqui. Todos os nossos parentes vivem longe, no Rio Grande do Sul. Se eu morresse, ficariam vocês desamparados; e, se não fossem muito amigos e muito unidos, a desgraça seria terrível...”. Passados dois meses de vida escolar, atentas, aplicadas, unidas pelo ensinamento paterno, as crianças receberam um telegrama com a notícia de que o pai adoecera, sem gravidade. Mas os meninos imediatamente imaginaram uma desgraça. E foi do mais velho, Carlos, que veio a ponderação: náo iria permanecer na incerteza. Iria para junto do pai. E partiria imediatamente. Não informaria a decisão ao diretor da escola com receio de que este o impedisse. E tal impulso foi logo acompanhado e reforçado pela convicção do menor de que também ele, Alfredo, o acompanharia. Não ficaria ali sem o irmão e na incerteza. Se juntaria ao irmão e permaneceriam juntos, obedecendo à ordem paterna de que deveriam ser unidos em todas as situaçóes da vida — tendo um só coração e uma só vontade...

O percurso das crianças, com aventuras, expectativas, inseguranças, imprevistos e encontros afetivos diversos, apoio de pessoas simples que se sensibilizavam com a desproteção daqueles menores, tudo isso argamassa a narrativa de viagem afetiva com o traçado da geografia, dos costumes e da cultura brasileira. Percorrem o território à busca do pai e encontram a pátria desenhada em seus matizes locais, atravessando o país do norte - de onde saíram os meninos, Recife - até a ponta do sul, onde finalmente se reencontram em família, no Rio Grande do Sul, terra natal da família paterna. O livro percorre o Brasil, suas características, sua diversidade, forjando o imaginário de hospitalidade, afetividade e generosidade da população espalhada pelos recantos de norte a sul. A diversidade dos costumes está expressa em cada forma de produzir específica de cada região: a colheita do café e a saga dos bandeirantes em Sáo Paulo, a movimentaçáo da populaçáo em inúmeras atividades pelas ruas do Rio de Janeiro, a exploração do pinho, no Paraná, a revolução dos Farrapos e a liderança de Anita Garibaldi em Santa Catarina, a cera de carnaúba das palmeiras do Ceará, e, assim, se desdobra a narrativa, em cada chegada dos irmáos a cada localidade do imenso Brasil. Por esta razão, o título, Através do Brasil.

A eleição do livro como motivação de abertura a esta reflexão vem do fato de ter sido o livro escrito por duas figuras exponenciais do pensamento social 
brasileiro que tiveram na educação forte referência à reflexão sobre o Brasil e à construção da nacionalidade. Olavo Bilac e Manoel Bomfim compóem a constelação dos intelectuais que identificaram na educação, ou por outra, na precariedade da educação brasileira, a fonte primordial de todos os nossos problemas. A República era devedora do que não cuidara até então, 20 anos passados da Proclamação. Em muitos aspectos, os traços da Primeira República estão refletidos na narrativa ficcional/didática do Através do Brasil. E é de tais aspectos que este texto tratará.

\section{Uma República por educar}

O Brasil da Primeira República (1889-1930), descrito pelos autores do livro que nos conduz, é um país de população em crescimento que chega, em 1900, aos 17 milhôes de habitantes. A população aumentaria em 10 vezes ao longo do século XX, aproximando-se hoje, na segunda década do século XXI, a uma cifra estimada em 192.738.419 habitantes. Mas o período que nos interessa, embora seja de uma população mais de 10 vezes menor, já apresenta crescimento importante a ponto de reclamar dos intelectuais e dos agentes públicos reflexão sobre rumos que tomaria o cenário nacional da República recém-implantada. Fatores externos foram os que mais contribuíram para o crescimento acelerado da população: o tráfico de escravos africanos até 1850 e a forte imigração entre 1870 e 1960. Portugueses, italianos, espanhóis, alemães e japoneses são os grupos mais notavelmente numerosos que, atraídos pela lavoura cafeeira do Sudeste e pelas áreas de colonização do Sul do país, viam na terra brasileira uma possibilidade de reconstrução de suas próprias vidas.

O Brasil do início da República era um país eminentemente rural (60\% da população em área rural), recém-saído do longo período de escravidão (mais de três séculos até a abolição da escravatura em 1888), com taxas nacionais de analfabetismo na ordem dos $75 \%$ da população. Um quadro de analfabetismo homogêneo com índices muito próximos de norte a sul do país, com exceção do Distrito Federal (Rio de Janeiro) cuja taxa rondava os 45\%. Nos demais estados da federação prevalecia a indicação do quanto faltava de investimento público em educação, uma área considerada estratégica ao desenvolvimento e ao cumprimento de ideais republicanos. 
O Brasil da Primeira República era também o país dividido entre os "políticos bacharéis" e os "homens de ação". A ruptura com o atraso brasileiro significava, para muitos desses homens, a reorganização, em bases racionais e técnicas, do trabalho agrícola, da fixação do homem rural, dos instrumentos e agências de produção. Embora majoritariamente rural, o Brasil já tomava contato com a aceleração urbana, e, simultaneamente, com a precariedade do investimento em educaçáo - fonte, àquela altura, primordial ao enfrentamento da necessária qualificação para o trabalho. Qualificação para o trabalho industrial e urbano, mas qualificação em não menor importância para os que iriam para a lavoura. Como se daria o trabalho no mundo rural até então associado ao escravo por trabalhadores livres? Estes são, à altura, pontos fortes quando nos deparamos com as justificativas de reformas e de investimento em educação.

Mas a precariedade atingia também a saúde. Saúde e educação formaram o binômio da Primeira República e motivaram o debate nacional que teve na década de 1920 seu apogeu. Atravessando o país em caravanas, os profissionais da ciência confrontaram-se com a doença no "imenso hospital” em que se transformara o Brasil, na expressão de Miguel Pereira (Bomeny, 1993:24-39). Buscando os novos cidadáos, os indivíduos brasileiros, encontraremos os educadores, espalhados pelos estados com seus experimentos empíricos, um verdadeiro laboratório de reformas, ideias e projetos, inspirados, em sua grande maioria, em modelos estrangeiros. De um lado, os cientistas da saúde Oswaldo Cruz (1872-1917), Belisário Pena (1868-1939), Artur Neiva (1880-1943), Carlos Chagas (1879-1934), Clementino Fraga (1880-1971) e Ezequiel Dias (1880-1927) levantavam o tema das doenças a demandar políticas públicas e educação sanitária; de outro, "os cientistas da pedagogia" Anísio Teixeira (1900-1971), Lourenço Filho (1897-1970), Fernando de Azevedo (18941974) e Francisco Campos (1891-1968) empunhavam a bandeira da educação como saída ao obstáculo que impedia ao país ultrapassar o ponto em que estava. As questóes da educação e da saúde foram de tal maneira identificadas como questóes cruciais, e com tal liga as duas esferas (educação e saúde) se imbricavam, que encontraremos como sua expressão formal a criação, em 1930, do Ministério para lhe fazer frente: Ministério da Educação e Saúde.

O período da Primeira República, as quatro décadas que a historiografia consagrou, presenciou uma movimentaçáo importante no campo educacional. 
Mas é possível distinguir as duas primeiras décadas das duas últimas. Muitos dos temas e da mobilização das duas primeiras décadas republicanas compareceram nas décadas de 1910 e 1920 . Estão lá os ingredientes que consubstanciaram a retórica de uma intervenção política que teve na década de 1920 a chance de se manifestar de forma mais organizada, e de âmbito nacional. É do que tratarei a seguir.

Um republicano de primeira hora: educação, trabalho e construção da nação

Das iniciativas de reformas educacionais das duas primeiras décadas da Primeira República, um exemplo pode ser ilustrativo do que estava em jogo quando a educação era evocada no período. Trarei como exercício uma experiência realizada em Minas Gerais, nos primeiros anos da República, e em meados da segunda década republicana — as escolas orientadas para o trabalho agrícola.

Completamente sintonizado com os males, as necessidades e as potencialidades de seu tempo, João Pinheiro da Silva (1860-1908) foi um empresário do final do século XIX e início do século XX, de Minas Gerais, que deixou como legado um projeto educacional. Republicano de primeira hora, um dos fundadores do Partido Republicano Mineiro (PRM) e um dos atores que se mobilizaram para a transferência da capital do estado de Minas Gerais. Deixava o estado a sinuosa e barroca cidade de Ouro Preto para a planejada e retilínea cidade de Belo Horizonte. João Pinheiro teve sua educação iniciada em seu estado natal, mas transferiu-se para São Paulo e se matriculou na Faculdade de Direito do Largo de São Francisco. Foi naquele ambiente que formou seu pensamento político e consolidou sua vocação republicana. Republicano, abolicionista e simpatizante de algumas das linhas de ação inspiradas no positivismo, João Pinheiro fez parte da família dos homens de ação - e em contraponto exemplar — um crítico contumaz do bacharelismo em todas as suas dimensôes: educacionais, políticas, culturais.

João Pinheiro foi uma liderança política do estado de Minas Gerais de início do século XX. Não hesitaria em identificar entre os males do Brasil o exagero da ênfase nas letras, o excesso de teoria, a pouca formação técnica, a 
precariedade da formação profissional. Um de seus colegas de turma - Rivadávia Corrêa — assinou a reforma educativa da década de 1910, a que retirava do Estado o poder de interferência sobre o ensino. Criticada em seus termos, a reforma foi muito pouco tempo depois recusada, fazendo com que retornasse ao Estado a responsabilidade pela condução do ensino público. Os termos da proposta de Corrêa deixavam evidentes as linhas de uma corrente liberal que via na liberdade da ação privada e nas consequentes iniciativas particulares a saída para vencer os obstáculos que a tradição pública impunha à ação social.

A intervenção de João Pinheiro em seu estado diferenciou-se da proposta de seu companheiro de geraçáo em muitos aspectos, sobretudo no que contemplava a participação da ordem pública na execução de política educacional. Homem de origem pobre, nascido no Serro, educado graças à ajuda de um irmão, e posteriormente de um tio, convenceu-se na escola da vida que é possível alcançar a ascensão social e o aprimoramento individual pelo esforço e dedicação ao trabalho. $\mathrm{O}$ ideal de um liberalismo à americana conformava a mentalidade e configurava a convicção de ser parte daqueles que se moveram pelo ideal do self made man. Em todos os seus discursos, a mística do esforço e do mérito associado ao empenho pelo trabalho prevalecia como fundamento do que defendia como ideal republicano de homens livres e educados. Sobretudo, na receita oferecida, a crença no sucesso da ligação entre instrução e progresso. Sua trajetória era o exemplo disponível à narrativa pela qual convencia os demais da urgência e da importância do investimento em educação. Sua morte súbita interrompeu um mandato de governador do estado no segundo ano de governo, em 1908. Mas as marcas de sua administração são, ainda em nossos dias, recuperadas positivamente na memória política do estado.

\section{A saída dos embaraços da tradição escravista}

A educação ocupou espaço central na atuação política de João Pinheiro. Nos vários argumentos de que se valeu para expressar a importância da educação no processo de desenvolvimento e modernização do estado de Minas Gerais, João Pinheiro ficou conhecido pela aversão aos caminhos e descaminhos da política, pela crítica ao ritualismo, à retórica da política, sempre identificando-os com ineficiência, inocuidade. Sua gestáo ficou marcada pelo prag- 
matismo das soluçôes de resultados visíveis, imediatos. Um executivo na política. Um executivo que tinha na economia o eixo estruturador da ação pública, fosse ela traduzida na prática parlamentar ou na proposiçáo das reformas necessárias à modernizaçáo do estado. "O meu pensamento capital [...] é a organização econômica. [...] o fato principal para mim não é a questão industrial, mas a questáo agrícola, e dentro desta o desenvolvimento da pequena agricultura." 1

A defesa da questão agrícola não fazia de João Pinheiro um adepto do agrarismo como ideologia de construçáo da nação brasileira. Havia certo realismo em sua proposição. Um país de 17.318.556 habitantes, dizia, dos quais 64\% com vida no campo, é um país que tem de prestar atenção à melhoria das condiçôes de funcionamento no próprio ambiente rural. Melhorar condiçôes implicava fixar o trabalhador ao solo e profissionalizá-lo. "O problema agrícola está imediatamente ligado ao programa de instrução, antes de tudo a técnico-profissional; um é consequência do outro. E, justamente porque a instrução é um fato capital, entendo que se deve a proteção à inteligência." ${ }^{2} \mathrm{~A}$ inferioridade brasileira estava diretamente ligada ao descuido com a educação popular. Terra e trabalho eram os motes da reforma proposta. E o americanismo foi o manto sob o qual se formulou a intervençáo educativa. Como Manoel Bomfim, João Pinheiro pode ser incluído na família dos críticos à tradição ibérica, na qual identificava boa parte dos impasses ao desenvolvimento nacional.

As duas curtas gestóes de João Pinheiro à frente do governo de Minas Gerais foram lembradas por intervençóes na educação, intervençóes que são hoje atualizadas permanentemente pela atuação de uma Fundaçáo que leva seu nome. O primeiro mandato como chefe do executivo estadual se deu no período de 1890-92, mandato interrompido deliberadamente descontente que estava com a orientaçáo imposta pelo governo do marechal Floriano Peixoto na presidência da república; e o segundo (1906-08) foi interrompido pela morte súbita, quando prescreveu a universalizaçáo do ensino primário e, em particular, a implementação das escolas agrícolas. Ensinar ao agricultor que tipo de produção é apropriado ao seu terreno, como lidar com a terra sem exauri-la, como lidar com máquinas, como modernizar o campo produtivo era

\footnotetext{
${ }^{1}$ Retirado de Bomeny (2005:145). A citação de João Pinheiro foi retirada de uma entrevista publicada no jornal O Paiz, Rio de Janeiro, 17 set. 1906.

${ }^{2}$ Acervo da Biblioteca Nacional. João Pinheiro e sua doutrina. Parte sobre a instruçáo, p. 58.
} 
a agenda de um currículo de Escola Agrícola. No programa de ensino técnico e prático três níveis foram considerados: 1) nas escolas primárias, sob a forma simples e elementar constituindo o curso técnico-primário; 2) nas fazendas-modelo - onde seriam admitidos os alunos que mais se distinguissem no curso primário - seria ministrado o ensino técnico prático, secundário; e 3) no estrangeiro, para onde seriam mandados por conta do Estado os alunos que se distinguissem no curso secundário e os industriais que obtivessem nas exposiçóes os melhores prêmios, os quais poderiam destacar o operário ou os operários que para tanto tivessem concorrido. Em todos os pontos perseguidos nas propostas de intervenção educacional, prevaleceu a conexão estreita entre educação e trabalho, educação e formação técnica para o melhor aproveitamento dos recursos disponíveis, educação e desenvolvimento econômico em bases liberais. A estratégia de governo se consolida na proposta de criação de um parque industrial, especialmente de indústria extrativa, e na racionalização das relaçóes de trabalho no campo.

As escolas agrícolas funcionariam como escolas de trabalho onde os praticantes estariam expostos às técnicas rudimentares da previsão, do cálculo, da economia e do lucro. O programa foi cuidado para alcançar o aprendizado implicado em toda a atividade: como fazer orçamento, como utilizar as máquinas, como aproveitar o solo até o momento da comercializaçáo nos mercados consumidores, mantendo como orientação a exposição permanente dos produtos em mercado maior, como o Rio de Janeiro, ponta de lança para circulaçáo da produção, além do aprendizado da divulgação comercial do que as escolas estimulavam. Ao Estado caberia a responsabilidade de assistir técnica e comercialmente os lavradores. João Pinheiro insistia no protecionismo produtivo ad tempore, ou seja, válido para o momento de transição entre uma indústria incipiente e a formação de um mercado industrial competitivo. E o modelo era o da pequena propriedade, já em sintonia com o que posteriormente transformou-se na política norte-americana de estímulo às pequenas propriedades produtivas. O projeto educacional incluía o ensino primário técnico, o ensino secundário técnico-profissional que estaria inserido no programa da escola pública, de modo concreto, sem teorias - um refrão em suas proposiçóes —, paralelamente ao ensino da leitura, da escrita e da aritmética. E o exemplo sempre recuperado: os Estados Unidos da América. A chave da modernização do país era a modernização do campo. Racionalizar e expandir o trabalho no 
campo, empreender a política protecionista, desde a cultura do café pelo Convênio de Taubaté, como de outras culturas, e preparar a mão de obra nacional. Esta é a síntese da proposta de desenvolvimento de Joáo Pinheiro.

As propostas de reforma estavam escoradas em um substrato comum: o reconhecimento dos obstáculos que a nação teria de enfrentar por um longo e danoso processo de trabalho baseado na escravidão. "Foi longo o nosso sofrimento, longo e pesado. A maldição do trabalho escravo nos legou este quinhão de dores que a geração atual está sofrendo, como todas as que vivem em época de transição."3 A associação de educação e trabalho tinha esta dupla face: educar o indivíduo para uma sociedade livre, não escravista, e alterar a feição negativa de que se revestia a atividade laboral. ${ }^{4} \mathrm{O}$ contexto que sustenta as preocupaçóes de Joáo Pinheiro foi sumarizado de forma clara por Nancy Leys Stepan em um livro indispensável à compreensão do sentido particular que a eugenia tomou na América Latina, e no Brasil em particular:

As mudanças ocorridas na região entre 1870 e 1914 foram imensas. No Brasil, por exemplo, em termos sociais, o período compreendeu o colapso final de uma sociedade escravocrata em 1888 (a última sociedade deste tipo no mundo ocidental) e a abertura do país à imigração europeia em grande escala. Politicamente, o período viu a queda da monarquia e a criaçáo da república, em 1889. Economicamente, testemunhou o crescente envolvimento brasileiro no sistema capitalista mundial, um envolvimento que manteve o Brasil em uma posição periférica de dependência, como fornecedor de matérias-primas como o café (Stepan, 2005:46).

A intervenção de João Pinheiro em Minas Gerais é representativa do diagnóstico que percorreu as duas primeiras décadas republicanas. Alguns dos efeitos de tal avaliação a respeito do despreparo da população para a convivência em sociedade livre foram também traduzidos em iniciativas de educação moral, orientação de higiene e saneamento. Fazia parte da agenda de positivar a atividade produtiva a ideia de que era preciso educar os indivíduos moralmente

\footnotetext{
${ }^{3}$ Editorial do jornal Minas Gerais de 12 de janeiro de 1908, cuja autoria é atribuída a João Pinheiro. In: Barbosa (1980:333).

${ }^{4}$ Os estudos de Angela de Castro Gomes são evidências do que foi mobilizado no início do século XX para o processo de construçáo de uma identidade social e política para o trabalhador brasileiro. A centralidade da educaçáo nesse movimento de restauração e instauração identitária pareceu a muitos dos homens políticos a condição sine qua non para sua implementação. Cf. Gomes (1988, 1990).
} 
preparando-os para a disciplina, para o trabalho e modelando o comportamento para o respeito às leis e aos códigos de conduta. Trabalho e moralidade, moralidade pelo trabalho, higiene corporal e mental, disciplina e respeito à hierarquia compuseram o ideal de construção da nação republicana como urgência a ser perseguida. A distância entre o ideal e as convulsivas manifestaçôes de despreparo e aglutinamento da população em espaços inadequados, desprotegidos, inóspitos, serviu de combustível a propostas de reformas educativas movidas pelo sentido de urgência, nem sempre melhor companheira do desempenho educacional. A educação foi invocada como mecanismo pelo qual muitas das mazelas, fruto de uma situação social convulsionada, poderiam ser minoradas ou controladas por um programa que atentasse para o valor do trabalho, da higiene, do condicionamento físico e da saúde moral. Um cenário onde os que habitavam o mais baixo degrau da hierarquia eram, contrariamente, os menos protegidos de toda sorte de preconceitos, atendimento ou atençáo do poder público. Ainda com Nancy Stepan (2005:46-47),

[...] O Brasil entrou no século XX como uma sociedade altamente estratificada, tanto social quanto racialmente - uma sociedade que, apesar de apresentar-se formalmente como república liberal, era informalmente governada por uma pequena elite, em sua maioria branca, e na qual menos de $2 \%$ da populaçáo votavam nas eleiçôes nacionais; uma sociedade em que a maioria das pessoas era negra ou mulata e analfabeta; em que, apesar da separação técnica entre Igreja e Estado, a Igreja Católica mantinha considerável influência; e na qual o liberalismo democrático era visto por muitos intelectuais como irrelevante ou prejudicial para o futuro do país.

Esse era o quadro geral da diferenciação social profunda e dos desafios postos ao ordenamento social na perspectiva da elite governante. As ideias de que o trabalho conformaria mentalidades mais disciplinadas e de que a fixação no solo evitaria convulsôes urbanas sustentaram o ideal republicano que transpareceu nos programas como o que levou adiante João Pinheiro. Liberalismo com ordenação e controle social pelo viés do trabalho.

Mas o investimento em educação agrícola tinha também um aspecto crucial na passagem da sociedade escravista para a sociedade do trabalho livre: fazer do aprendizado de ofícios no ensino primário uma fonte de cultivo de 
nova mentalidade a respeito do trabalho manual. Afinal, o trabalho no próprio campo seria, depois da abolição, feito por não escravos, em geral, por brancos livres. Toda a carga negativa associada ao mundo rural escravocrata teria de ser retirada e progressivamente incorporada como habilidade de trabalhadores do setor agrário. Pesquisadores ${ }^{5}$ da história política de Minas Gerais já cuidaram desse tema com sugestóes bastante convincentes. "Com a economia republicana, predominantemente agrícola, notou-se a necessidade de amenizar as antigas relaçôes com o trabalho manual para o emprego de trabalhadores livres nos campos", nos diz Kellen Tarciana de Almeida, em sua dissertação de mestrado defendida em Belo Horizonte em 2009, pesquisa já beneficiada por um conjunto de trabalhos que abriram caminhos nesta perspectiva. A referência oficial de proposição desse projeto educacional econômico foi o primeiro Congresso Agrícola, Industrial e Comercial de Minas Gerais, em maio de 1903 em Belo Horizonte, a recente capital que então completaria em dezembro seus seis anos de vida. Tudo era novo. A reorientação político-econômica do estado com a nova capital, a redefiniçáo de relaçóes de trabalho com vistas ao desenvolvimento capitalista e o esforço de uma sociedade em preparar os trabalhadores para o novo tipo de contrato. A revalorização do trabalho manual talvez tenha se constituído na estratégia proposta pelo Estado em atendimento a demandas das classes produtoras. O trabalho regular e metódico da lavoura exigiria outro comportamento dos trabalhadores que antes, nas palavras de Faria Filho, "donos apenas de sua força de trabalho", eram convocados agora para as minas, a siderurgia, a lavoura. Um problema que as elites dirigentes mineiras tiveram de enfrentar durante o século XIX e que, com urgência, após a abolição, tiveram de responder de forma mais permanente. Aliás, este era um problema que estava longe de ser exclusivo do estado de Minas Gerais. Em todo o país, a precariedade da mão de obra que deveria substituir a massa de escravos transformava-se em questáo posta às elites e à própria sociedade. Diferente de São Paulo, Minas não havia recebido o contingente de imigrantes que se incorporou à vida social e econômica paulista. $\mathrm{O}$ contingente de livres e pobres em Minas em um primeiro momento parecia sugerir que hou-

\footnotetext{
${ }^{5}$ Almeida (2009). Ver também: Cunha (2000); Dulci (1999); Faria Filho (1990, 2001).
} 
vesse uma solução local apropriada à reconversão. As dificuldades, no entanto, foram bem mais extensas do que o previsto.

No caso de Minas Gerais, a reordenação da sociedade em nível legal foi colocada em discussão e contemplada durante o Congresso de 1903. Na ocasião, membros das elites políticas e econômicas do Estado exigiram leis que reprimissem as resistências dos trabalhadores nacionais e mineiros em relação à ordem do trabalho disciplinado dos campos, assim como pela tese que defendia a constituição da força de trabalho via educação (Almeida, 2009:21).

Na proposta de João Pinheiro, como bem salientou Faria Filho, a reeducação vinha da infância. Uma formação elementar daqueles que seriam os trabalhadores de amanhã. Todos os ingredientes entravam na composição da noção de perigo e ameaça à sociedade livre e próspera: ócio, indisciplina, abandono nas ruas, falta de higiene. Com todas as antenas ligadas nos temores resultantes de tais combinaçóes, encontramos o projeto de um governante que pretendia associar o projeto de educação profissional com a ideia de inequívoco desenvolvimento econômico e social. Nas palavras de Otávio Dulci é possível perceber a extensão da proposta de um projeto desenhado no feitio adequado à Primeira República:

[...] João Pinheiro, com sua convicção positiva, foi o principal idealizador dessa política. Concebia para o estado uma missão pedagógica de educar a população para o progresso. E, para isso, era preciso inverter prioridades. Em consequência, dedicou-se a um esforço simultâneo de expandir o ensino primário e de criar estabelecimentos de aprendizagem agrícola - fazendas-modelo e campos de experiência e demonstração - , que se somavam ao serviço de instrutores ambulantes, na divulgação de novas técnicas e do uso da mecanização... (Dulci, 1999:131).

A população alvo era a população pobre. A mais vulnerável à desagregação, a influências nocivas quando desocupada, aos vícios e aos crimes. As elites estavam atentas (e temerosas) a todo esse conjunto de possibilidades. O Congresso de 1903 foi um momento consagrador do estímulo à política de preparação de crianças para um destino alternativo ao que o ambiente náo educado fatalmente provocaria. A criaçáo do Instituto Joáo Pinheiro pelo estado de 
Minas Gerais foi direcionada aos desvalidos da sorte desde a infância. Formar futuros trabalhadores para a agricultura, oferecer noções básicas de profissões urbanas, formar o caráter da criança e cuidar de noçôes de higiene e disciplina eram as metas mobilizadas em uma organizaçáo construída para o cruzamento de grande fecundidade que a Primeira República consolidou em Minas, mas que o país como tal foi igualmente sensível: educação para o trabalho. A última década da Primeira República transformou tais princípios em bandeiras de ação tanto por associaçóes como por intelectuais educadores protagonistas do que resultou, ao fim e ao cabo, em um Ministério próprio para sua gerência e consolidação. Vejamos como.

\section{A movimentação pré-Ministério da Educação e Saúde}

Dois acontecimentos, um de natureza cívica, e outro de cunho político organizacional com repercussão no campo educacional, são sempre evocados para tratar da educaçáo na Primeira República. São iniciativas simbólica e empiricamente importantes para nos deixarem as linhas básicas do que estava em questão à época. Abro com a criação da Associação Brasileira de Educação (ABE), em 1924, no Rio de Janeiro, e sigo com as reformas educativas que se espalharam pelo país na década de 1920. Ambos os movimentos, estreitamente relacionados, são sínteses expressivas da atmosfera republicana forjada nas suas duas primeiras décadas, prenhe do desapontamento diante dos efeitos negativos de uma sociedade analfabeta e, por isso, distanciada das possibilidades abertas ao experimento moderno. O livro de Marta Maria Carvalho, Molde nacional e fôrma civica, é referência nos estudos sobre a ABE; e o livro de Jorge Nagle, Educação e sociedade na Primeira República, tem sido recuperado em todos os estudos sobre o período, criando a ambiência sobre a qual se justificaria o empreendimento de disseminação da educação como bem a ser cultivado nacionalmente. As duas referências não esgotam o panorama de pesquisas e textos sobre esses eventos, mas foram selecionadas até por certo contraste que a autora de Molde nacional e fôrma cívica quis imprimir à sua contribuição com relaçáo a que nos ofereceu Nagle. Em linhas gerais, o apanhado sobre a educaçáo no período pós Proclamaçáo da República, tal como protagonizada e dis- 
seminada por Nagle, confere à atmosfera do período o adensamento de uma aposta na educação e em seu desenvolvimento como solução do que foi diagnosticado como o problema nacional. A expressão cunhada por ele, "entusiasmo pela educaçáo", como que traduziria a adesão coletiva a uma ideia, uma bandeira, a partir da qual outros desdobramentos efetivos poderiam ser detectados. A segunda e consequente expressão, "otimismo pedagógico", alimentaria o entusiasmo, acrescendo o poder da educação especializada, educação moldada segundo avanços científicos do campo pedagógico na formação de um homem novo para uma sociedade que igualmente desafiava pela emergência do novo. A atmosfera cívica prevaleceria nesse tipo de abordagem, e também prevaleceria certa despolitização do processo que, ao fim e ao cabo, dinamizou a movimentação pela educação na Primeira República, como quis sugerir Nagle. É em resposta a esta interpretação de despolitização sugerida por Nagle que Marta Carvalho formula sua própria tese a respeito dos movimentos que tiveram na Associação Brasileira de Educação base importante de sustentação e legitimação. Carvalho expressa assim sua anotação:

O "entusiasmo pela educação" caracterizar-se-ia pela importância atribuída à educação, constituída como o maior dos problemas nacionais, problema de cuja soluçâo adviria o equacionamento de todos os outros. O "otimismo pedagógico" manteria, do "entusiasmo", a crença no poder da educação, mas não de qualquer tipo de educação, enfatizando a importância da "nova” pedagogia na formação do homem novo. A expressão "profissionais da educação" designa a emergência do "técnico", no movimento designado como "otimismo pedagógico", indicando a crescente dissociação que se produz no movimento entre problemas sociais, políticos e econômicos e problemas pedagógicos (Carvalho, 1998:32).

Em uma cadeia sucessiva, cada um desses níveis alimentaria seu desdobramento em outro indicando movimento progressivo de ação: crença na educação como solução de problema nacional pelo reconhecimento coletivo do problema nacional como derivado da precariedade da educação do povo; a decisão de implementar ação educacional como consequência da crença coletiva e o reconhecimento de que a ação bem-sucedida dependeria da qualificaçáo técnica dos protagonistas. 
Mas a Associação Brasileira de Educação (ABE) foi política em seus fundamentos, defende Carvalho. A ABE foi oficialmente criada em outubro de 1924 por um grupo de 13 intelectuais da cidade do Rio de Janeiro, em uma sala da Escola Politécnica do Rio de Janeiro. O trajeto até a Associação foi descrito por Marta Carvalho e vale a pena persegui-lo: inicialmente havia a intenção de criar uma Federação de Associações de Ensino, ao que se sucedeu o propósito de organização de um partido político - a Acção Nacional — e, finalmente, do malogro da última tentativa, emerge a Associação Brasileira de Educação. O fracasso da Revolução Paulista de 1924 provocou o acirramento da repressão política que se estendeu ao Rio de Janeiro desestimulando a iniciativa de cunho mais nitidamente político do partido e a confirmação de uma Associação com fins pedagógicos: "promover no Brasil a difusão e o aperfeiçoamento da educação em todos os ramos e cooperar em todas as iniciativas que tendam, direta ou indiretamente, a esse objetivo". ${ }^{6}$

A disseminação dos ideais propagados pela Associação Brasileira de Educação e um conjunto importante de reformas educacionais em muitos dos estados da federação fortaleceram a crença de que a primeira república, sobretudo na década de 1920, protagonizou uma revolução no campo da educação pública no país. E não foram completamente desprovidos de fundamento os exemplos evocados para credenciar a década como a década educacional. Vejamos: São Paulo (1920), Distrito Federal (1922 e 1928), Minas Gerais (192728), Pernambuco (1928), Paraná (1927-28), Bahia (1928) são alguns dos principais cenários que acolheram reformas educacionais registradas na historiografia educacional da Primeira República. Sem mencionar pelo menos três que ocuparam a década anterior, que já sinalizava o problema republicano da oferta da educação em uma sociedade que alterava progressivamente seu perfil na direção da urbanização.

\footnotetext{
${ }^{6}$ Carvalho (1998:54-55). A citação é retirada dos Estatutos da Associação Brasileira de Educaçáo, aprovados em Assembleia Geral de 16 de outubro de 1924 e modificados em Assembleia Geral de 2 de outubro de 1926, Art. 1, segundo informa a autora.
} 


\section{Movimentação Educacional — Primeira República}

\begin{tabular}{|c|c|c|c|}
\hline ANO & NOME REFORMA & $\begin{array}{l}\text { ESTADO } \\
\text { FEDERAÇÃO }\end{array}$ & CONTEÚDO \\
\hline \multicolumn{4}{|c|}{$\begin{array}{l}\text { 1889: matriculados } \\
12 \% \text { da população } \\
\text { em idade escolar }\end{array}$} \\
\hline 1890 & $\begin{array}{l}\text { Reforma } \\
\text { Benjamin Constant }\end{array}$ & & $\begin{array}{l}\text { Ensino leigo e livre em todos } \\
\text { os graus e gratuito no primário. } \\
\text { Substituir orientação literária } \\
\text { pela científica. }\end{array}$ \\
\hline 1891 & & & $\begin{array}{l}\text { Constituição estipula ensino leigo } \\
\text { nas escolas públicas em oposição ao } \\
\text { ensino religioso. }\end{array}$ \\
\hline 1911 & $\begin{array}{l}\text { Lei Orgânica de } \\
\text { Rivadávia Corrêa }\end{array}$ & & $\begin{array}{l}\text { Estabelece ensino livre e retira do Es- } \\
\text { tado o poder de interferência no se- } \\
\text { tor educacional. }\end{array}$ \\
\hline 1915 & $\begin{array}{l}\text { Lei do ministro } \\
\text { Carlos Maximiliano }\end{array}$ & & $\begin{array}{l}\text { Reoficializa o ensino; restabelece } \\
\text { a interferência do Estado retirada } \\
\text { pela reforma anterior. }\end{array}$ \\
\hline 1920 & $\begin{array}{l}\text { Reforma } \\
\text { Sampaio Dória }\end{array}$ & São Paulo & $\begin{array}{l}\text { Reconduzir a educação para novos } \\
\text { métodos de ensino. Alfabetizar em } \\
\text { massa as crianças do estado em um } \\
\text { curso primário reduzido a dois anos } \\
\text { de duração e duas horas e meia } \\
\text { diárias de aula para ampliar número } \\
\text { de vagas. }\end{array}$ \\
\hline 1922 & $\begin{array}{l}\text { Início da Reforma } \\
\text { Carneiro Leão } \\
(1887-1966) \text { no } \\
\text { Rio de Janeiro }\end{array}$ & & $\begin{array}{l}\text { Ênfase dada à organização da } \\
\text { educação popular (educação física, } \\
\text { trabalhos manuais, formação } \\
\text { do professor). Crítica ao ensino } \\
\text { literário e retórico. }\end{array}$ \\
\hline 1923 & $\begin{array}{l}\text { Lourenço Filho inicia } \\
\text { movimento de renova- } \\
\text { ção educacional com } \\
\text { Reforma Educativa }\end{array}$ & Ceará & $\begin{array}{l}\text { Proposta dos Testes ABC para verifi- } \\
\text { cação de maturidade necessária à } \\
\text { aprendizagem da leitura e da escrita. }\end{array}$ \\
\hline 1924 & $\begin{array}{l}\text { Criação da Associação } \\
\text { Brasileira de Educação } \\
\text { por Heitor Lira, Antonio } \\
\text { Carneiro Leão, Venâncio } \\
\text { Filho, Everardo Backeu- } \\
\text { ser, Edgard Sussekind } \\
\text { de Mendonça, Delgado } \\
\text { de Carvalho... }\end{array}$ & & \\
\hline
\end{tabular}




\begin{tabular}{|c|c|c|c|}
\hline 1925 & $\begin{array}{l}\text { Reforma (Reforma } \\
\text { Góes Calmon) conduzi- } \\
\text { da com princípios esco- } \\
\text { lanovistas do educador } \\
\text { Anísio Teixeira }\end{array}$ & Bahia & $\begin{array}{l}\text { A Lei no } 1.846 \text {, de } 14 \text { de agosto de } \\
1925 \text {, dispunha com detalhes sobre } \\
\text { os princípios da gratuidade e obriga- } \\
\text { toriedade do ensino e deixava claro } \\
\text { que o ensino no Estado da Bahia } \\
\text { "tem por objetivo a educação física, } \\
\text { intelectual e moral do indivíduo de } \\
\text { modo a formar homens aptos para a } \\
\text { vida em sociedade e cidadãos úteis à } \\
\text { comunhão nacional". }\end{array}$ \\
\hline 1926 & $\begin{array}{l}\text { Fernando de Azevedo } \\
\text { dirige inquérito sobre } \\
\text { educação pública }\end{array}$ & São Paulo & \\
\hline 1927 & $\begin{array}{l}\text { Reforma Francisco } \\
\text { Campos e Mario } \\
\text { Casassanta (MG); } \\
\text { Reforma Lisímaco Costa } \\
\text { (Paraná); } \\
\text { I Conferência Nacional } \\
\text { de Educação promovida } \\
\text { pela ABE, em Curitiba }\end{array}$ & $\begin{array}{l}\text { Minas } \\
\text { Gerais; } \\
\text { Paraná }\end{array}$ & \\
\hline 1928 & $\begin{array}{l}\text { Reforma do Distrito } \\
\text { Federal (Fernando } \\
\text { de Azevedo); } \\
\text { Reforma Carneiro Leão } \\
\text { (Pernambuco) }\end{array}$ & DF; PE & $\begin{array}{l}\text { Decreto } 3.281 \text {, de } 23 \text { de janeiro de } \\
\text { 1928. Ensino Técnico Profissional, } \\
\text { Ensino Primário e Ensino Normal. } \\
\text { "Preparar gerações para a vida so- } \\
\text { cial de seu tempo" (FA). Criação de } \\
\text { Conselhos Escolares - ligação com } \\
\text { o mundo da produção. }\end{array}$ \\
\hline 1930 & $\begin{array}{l}\text { Criação do Ministério } \\
\text { da Educação e Saúde } \\
\text { Pública, Decreto } 19.402\end{array}$ & & $\begin{array}{l}\text { Taxa de matrícula nas escolas corres- } \\
\text { ponde a } 30 \% \text { da população em ida- } \\
\text { de escolar. }\end{array}$ \\
\hline
\end{tabular}

A década de 1920 ficou marcada na historiografia brasileira por fatos relevantes associados ao esforço de promoção de mudanças nos costumes políticos brasileiros. Foi nessa década que se registraram o Movimento dos 18 do Forte (1922), a Semana de Arte Moderna (1922), a fundaçáo do Partido Comunista Brasileiro (1922), a Revolta Tenentista (1924) e a Coluna Prestes (1924 a 1927). O ambiente político da década de 1920 e o conjunto de interpretaçóes a respeito do período fortalecem a ideia de que a bandeira da educaçáo esteve fortemente associada ao que se considerava o grande obstáculo à passagem da sociedade tradicional, personalista, escravista, socialmente poluída à sociedade moderna, higienizada, qualificada para o trabalho industrial. Talvez tal ênfase tenha consolidado a proeminência de linhas da reforma educativa sintonizadas mais de perto com a situação social efervescente em São Paulo, no início do 
desenvolvimento de uma indústria a indicar a precariedade da formação do trabalhador. Se as reformas não se restringiram em suas apresentaçôes programáticas aos temas específicos da profissionalização e da higiene moralizadora representadas em aspectos físicos aprimorados pela educação física e aspectos morais com a sinalização de conduta adequada — educação moral e cívica —, nenhuma delas, espalhadas pelos estados da federaçáo, pôde desconhecer ou refutar o lugar dessas prioridades nos projetos de reforma. Este me parece o sentido mais específico da crítica de Marta Carvalho à interpretação de Nagle. A mobilização nacional, ou a consciência nacional em torno da importância da educação, foi circunscrita, em sua grande extensão, aos objetivos mais instrumentalizados e pragmáticos de uma preparação física, moral e profissional para o que se nomeava como "novos tempos", aqueles informados pela atividade industrial.

\section{Referências}

ALMEIDA, Kellen Tarciana de. O ensino primário agrícola: o caso do Instituto João Pinheiro em Minas Gerais (1909-1942). Dissertação (mestrado em educação tecnológica) - Centro Federal de Educação Tecnológica de Minas Gerais, Belo Horizonte, 2009.

BARBOSA, Francisco de Assis (Org). Ideias politicas de João Pinheiro: cronologia, introdução, notas bibliográficas e textos selecionados. Brasília: Senado Federal; Rio de Janeiro: Fundação Casa de Rui Barbosa, 1980.

BOMENY, Helena. Novos talentos, vícios antigos: os renovadores e a política educacional. Estudos Históricos, Rio de Janeiro, v. 6, n. 11, p. 24-39, 1993.

O Brasil de João Pinheiro: o projeto educacional. In: GOMES, Angela de Castro (Org.). Minas e os fundamentos do Brasil moderno. Belo Horizonte: Editora UFMG, 2005. p. 137-166.

CARVALHO, Marta Maria. Molde nacional e fôrma cívica. Bragança Paulista: Edusf/ CDAPH, 1998.

CUNHA, Luiz Antônio. O ensino de ofícios nos primórdios da industrialização. São Paulo: Unesp; Brasília: Flacso, 2000.

DULCI, Otávio Soares. João Pinheiro e as origens do desenvolvimento mineiro. In: GOMES, Angela de Castro (Org.). Minas e os fundamentos do Brasil moderno. Belo Horizonte: Editora da UFMG, 1999. p. 109-136.

FARIA FILHO, Luciano Mendes de. A República do Trabalho: a formação do traba- 
lhador-cidadáo no alvorecer do século XX. Cadernos do Departamento de Ciência Política, Belo Horizonte, n. 8; Revista do Departamento de História, n. 10, Belo Horizonte, p. 79-92, 1990. (número conjunto)

República, trabalho e educação: a experiência do Instituto João Pinheiro: 1909/1934. Bragança Paulista: Ed. USF, 2001.

GOMES, Angela de Castro. A invenção do trabalhismo. Sáo Paulo: Vértice; Rio de Janeiro: Iuperj, 1988.

_. República, trabalho e cidadania. Rio de Janeiro: CPDOC/FGV, 1990. (Cadernos CPDOC)

NAGLE, Jorge. Educação e sociedade na Primeira República. São Paulo: EPU; Rio de Janeiro: Fundação Nacional de Material Escolar, 1974.

STEPAN, Nancy Leys. A hora da eugenia: raça, gênero e naçáo na América Latina. Tradução de Paulo M. Garchet. Rio de Janeiro: Fiocruz, 2005. 